\title{
Uma análise de $O$ tambor de Günter Grass: recursos ficcionais para debater sua própria história
}

\author{
[An analysis of The Tin Drum from Günter Grass: fictional resources to \\ defend his own story] \\ http://dx.doi.org/10.11606/1982-883721351
}

Milena Hoffmann Kunrath ${ }^{1}$

\begin{abstract}
This article seeks to study the fictional resources employed by writer Günter Grass in his most famous literary work, The Tin Drum, in which the author recreates his own story through the main character, Oskar Matzerath. For this purpose, the article contrasts the fictional work The Tin Drum with the German author's autobiography, along with the tribulations of his personal trajectory.
\end{abstract}

Keywords: Günter Grass, The Tin Drum, German literature

Resumo: Busca-se neste artigo analisar os recursos ficcionais utilizados pelo escritor Günter Grass em sua obra literária mais famosa, $O$ tambor, na qual o autor recria, através do protagonista, Oskar Matzerath, sua própria história. Para tanto, o artigo coteja a obra de ficção $O$ tambor com a autobiografia do autor alemão, juntamente com os percalços de sua trajetória pessoal.

Palavras-chave: Günter Grass, $O$ tambor, literatura alemã

\section{Introdução}

O escritor Günter Grass - prêmio Nobel de Literatura de 1999, ex-combatente da Segunda Guerra Mundial, artista plástico e politicamente engajado - desperta, na Alemanha, opiniões extremas: amor ou ódio. O certo é que ninguém permanece indiferente a sua figura. A obra principal do autor ( $O$ tambor), da mesma forma que suas intervenções posteriores, também causou, no seu lançamento, grande impacto na sociedade alemã e, por que não, mundial. Apesar do relato quase fantástico narrado pelo protagonista, o

\footnotetext{
${ }^{1}$ Universidade Federal de Pelotas, Rua Gomes Carneiro, 1, Pelotas, RS, 96010-610, Brasil. E-mail: milena.kunrath@gmail.com.
}

\section{(c))BY-NC}


Kunrath, M. - Uma análise de O tambor de Günter Grass

romance não só nos remete a fatos históricos: ele nos força à inevitável comparação entre protagonista e autor. Grass e Oskar partilham a nacionalidade, a mãe católica cassúbia e o pai protestante alemão, o tio que morre na defesa do correio polonês e até mesmo a "isenção" da culpa que grande parte dos alemães carregou depois do fim da guerra. $O$ tambor foi a forma encontrada por Grass, utilizando suas recordações e força criativa, de reconstruir sua história e divulgar seus pontos de vista sobre a época nazista e a Alemanha pós-guerra.

\section{$2 \bigcirc$ autor como criador de sua própria história}

Pode-se dizer que $O$ tambor, de Günter Grass, é quase uma biografia - não de uma pessoa só, mas de uma visão de mundo, de um mundo dissecado, retratado com uma crueza e veracidade que chegam a assustar. Os personagens não são bons nem maus, mas oportunistas que lutam pela sobrevivência em tempos de crise e desejam ardentemente aparentar uma civilidade que não lhes é inerente. Enfim, humanos. Oskar é o narradorprotagonista, segundo o modelo de Friedman (1996), já que é, ao mesmo tempo, narrador e principal personagem de sua história. Internado em um hospício, decide contar, inspirado pelo som de seu tambor de lata, a sua história:

O relato [...] inicia com o nascimento da mãe de Oskar e termina quando este completa trinta anos de idade e 1 metro e 23 centímetros de altura. Estes anos contemplam duas guerras mundiais, mas principalmente a reconstrução da Alemanha, e a chance de todos, ou quase todos, representarem, do zero, novos papéis (KUNRATH 2009: 5).

Tudo o que sabemos sobre os personagens e a história dá-se através do próprio narrador, no caso o narrador-personagem Oskar Matzerath. Já que o narrador é o protagonista, não há uma onisciência quanto aos outros personagens. Nós, os leitores, somos então privados de uma visão mais ampla, e nosso conhecimento dos fatos será sempre através da perspectiva do personagem principal, ou seja, segundo Friedman (1996: 84), "El narrador-protagonista, por ende, debe limitarse casi exclusivamente a sus propios pensamientos, sentimientos y percepciones. De igual modo, el ángulo de visión es el de un centro fijo".

Logo após a guerra, os alemães dividiam-se entre aqueles que acreditavam que o nazismo havia surgido das mentes maliciosas de um pequeno grupo de líderes, e aqueles que afirmavam que o resultado dos desmandos de Hitler não teria ocorrido sem o respaldo 
Kunrath, M. - Uma análise de O tambor de Günter Grass

da população, e que, por isso, todos deviam assumir o encargo de expiar e refletir sobre seus pecados de guerra. Günter Grass, como cidadão engajado, fazia parte desta última vertente.

Alguns dos recursos utilizados para atingir este fim fogem às explicações clássicas: segundo Pouillon, espera-se que, num "romance ideal", o leitor tenha certa empatia com o modo de pensar do narrador: "Para que me seja possível adquirir uma consciência das coisas e das pessoas, idêntica à do herói do romance, é preciso que este pertença a um mundo mentalmente semelhante ao meu" (PouILlon 1974: 60). No romance de Grass, isso certamente não acontece. O personagem-narrador não espera empatia de ninguém, nem se esforça para isso; sua conduta e pensamento amoral não pretendem convencer o leitor, nem julgam as atitudes condenáveis praticadas pelos outros personagens. Pouillon (1974: 60) afirma, sobre as histórias em que não há empatia entre o leitor e o narrador, que “[...] em alguns romances notáveis, nós encontramos este mesmo processo empregado com intenção radicalmente oposta, visto tratar-se de nos colocar 'com' seres profundamente diferente de nós".

Através da visão privilegiada de uma "criança" já mental e espiritualmente pronta desde o nascimento, $O$ tambor chocou a sociedade alemã por expor o regime do qual ela foi capaz de fazer parte com uma indiferença resignada. O livro serviu aos propósitos do autor ao exibir a contradição dos repetidos discursos "nós não sabíamos de nada" ou "nós apenas cumprimos ordens", com os benefícios pessoais com os quais cada um foi comprado. Pouillon percebe o paradoxo deste tipo de romance com a perplexidade do leitor, e continua:

A incoerência das visões que os personagens têm dos acontecimentos que lhes sucedem
e que transparece nas narrativas dos mesmos feitas por esses personagens - tem como
finalidade transmitir-nos diretamente a consciência de si de um primitivo, sem precisar
recorrer a reconstruções conceituais ou a comentários psicológicos (POUILLON 1974: 54).

Ou seja, o leitor alemão do pós-guerra não é convidado a fruir de uma história, e nem gozará de empatia. Ele não será compreendido, nem perdoado. Em algum momento, seus pecados serão expostos, e o tambor de lata de Oskar martelará: eu sei o que você fez, mas não dou a mínima importância. Você terá que lidar com isso sozinho, com a sua consciência: a mim, você não engana. Por ser conduzido por um personagem amoral, a narração afeta as almas mais sensíveis. Cenas em que Oskar, já com 16 anos, mas 
Kunrath, M. - Uma análise de O tambor de Günter Grass

aparência (e pressuposta mentalidade) de três, se relaciona com sua babá, e a sugestão de que o filho que ela gera possa ser seu repugnam boa parte do público.

Sim, Oskar tudo sabe e tudo percebe, mas não por possuir habilidades sobrenaturais ou divinas. A narrativa fantástica, em que uma criança espiritual e intelectualmente formada decide parar de crescer, não a dota de tais poderes "mágicos". O mesmo resultado é alcançado por caminhos menos fáceis. Grass se utiliza de diversas técnicas narrativas: "Uma dessas consiste na combinação da mais rigorosa observância da realidade histórica com uma fantasia extrema, definida algumas vezes como 'surrealista"” (MAZZARI 1999: 117). Oskar, por sua mentalidade, é capaz de compreender e narrar a forma de pensar dos personagens: ele analisa friamente as atitudes dos parceiros de cena conforme o que testemunha. Além disso, o anão possui outra grande vantagem: ao se apresentar como criança, possui acesso a um mundo de informações dos adultos sem qualquer censura prévia. Para Mazzari, a respeito das dimensões liliputianas de Oskar Matzerath:

Elas possibilitam-lhe acesso a todos os lugares que deseja: embaixo da mesa sobre a qual os adultos jogam baralho ao mesmo tempo que desenvolvem com os pés um jogo erótico; em vestiários femininos e em algumas camas de mulheres; sob as saias de sua avó Anna, único lugar em que encontra proteção e aconchego; também sob tribunas, durante manifestações políticas que ele busca sabotar com o tambor (MAZZARI 1999: 42).

Grass precisa de Oskar, segundo Mazzari (1999: 42), para ser uma testemunha coerente que realmente presenciou os fatos que narra daquela perspectiva. Com a exceção dos anos anteriores a seu nascimento, Oskar testificou tudo o que foi narrado, da ascensão à queda do regime nazista e o envolvimento do povo alemão durante o processo. HansMagnus Enzensberger (1968) explica o resultado do método de escrita do autor:

Esse autor aferra-se, tal como seu herói, nas malditas nódoas da realidade de maneira que sua ficção fantasiosa desiste do espírito da aproximação que ainda se torna a obsessão pela evidência irrefutável. O que produziu um realismo tão bem arranjado mostra-se, por exemplo, no tempo histórico da base do romance. Eu não conheço nenhuma representação épica do regime de Hitler que se deixe comparar em precisão e convencimento, no qual Grass, além disso paralelamente sem fazer o mínimo de apelo ao antifascismo, forneceu em $O$ tambor $^{2}$ (ENZENSBERGER, 1968: 10, tradução nossa).

\footnotetext{
2 'Dieser Autor verbeißt sich, wie sein Held, in die 'verdammten Flecken' der Wirklichkeit dergestalt, da $\beta$ seine phantastische Fiktion den Geist des Ungefähren aufgibt, da $\beta$ noch die Obsession zur unwiderlegbaren Evidenz wird. Was so ein beschaffener Realismus leistet, zeigt sich beispielsweise an der zeitgeschichtlichen Grundierung des Romans. Ich kenne keine epische Darstellung des Hitlerregimes, die
} 
Kunrath, M. - Uma análise de O tambor de Günter Grass

Enquanto que Enzensberger compara Oskar Matzerath e Günter Grass de forma direta, poderia-se pensar em formas menos imediatas como sugere o conceito do "autor implícito" de Wayne Booth (1980). Mesmo que a opinião de Grass não tenha representação explícita no romance, ela se faz perceptível através das formas da representação. Seu protagonista não se preocupa em condenar a imoralidade das atitudes dos seus contemporâneos, mas o leitor compreende perfeitamente a atitude crítica da instância que organiza e formula a narrativa do Oskar. Para Booth:

O sentido que temos do autor implícito inclui não só os significados que podem ser extraídos, como também o conteúdo emocional ou moral de cada parcela de acção e sofrimento de todos os personagens. Inclui, em poucas palavras, a percepção intuitiva de um todo artístico completo; o principal valor para com o qual este autor implícito se comprometeu independentemente do partido a que pertence na vida real - isto é, o que a forma total exprime (ВоOTH 1980: 91).

Ademais, o realismo quase forçado é associado à falta do julgamento moral contundente que se esperaria de um livro sobre os anos da ditadura nazista. Isso contrasta com o conhecimento que temos acerca da trajetória do escritor Günter Grass, o qual não tem, de forma alguma, de acordo com sua postura pública, entrevistas e livros publicados, uma visão acrítica dos fatos que presenciou. Grass apenas orientou o seu protagonista de forma a conduzir o leitor, por outros meios, a uma conclusão considerada óbvia.

Através de Pouillon podemos ainda decifrar outro aspecto central deste tipo de narrativa: Oskar é, mas também não é, Günter Grass. As semelhanças entre os dois (cidade e época de nascimento, origem familiar e características dos familiares, ocupação dos mesmos espaços - Danzig e mudança para o leste no pós-guerra, envolvimento com a escola superior de artes/talentos artísticos, etc.), que são praticamente anuladas devido à narrativa fantástica, mostram que Grass precisa contar sua história, mas não se comprometer com uma veracidade histórica nem se deter em explicações sobre suas escolhas.

Mazzari (1999) reafirma o rumo que o autor pretende seguir: encontrar uma coerência dentro da narrativa absurda para tornar a história mais realista. Fica a pergunta: será por esse motivo - o reconhecimento do leitor nas situações absurdas narradas pelo herói - que grande parte da sociedade alemã se ofendeu tão profundamente pela publicação da obra de Grass? Mazzari responde da seguinte forma:

sich an Prägnanz und Triftigkeit mit der vergleichen ließe, welche Grass, gleichsam nebenbei und ohne das mindeste antifaschistische Aufheben zu machen, in der Blechtrommel liefert." 
Kunrath, M. - Uma análise de O tambor de Günter Grass

A existência de Oskar não se encontra solta no espaço e desvinculada de toda e qualquer realidade. Insere-se, muito pelo contrário, em uma realidade histórica bastante precisa; a vida das pessoas que o cercam e com as quais convive à sua maneira é condicionada pelo desenvolvimento político e social da época. Dessa forma, o leitor de suas memórias não se vê diante de imagens fantasmagóricas, aberrações imaginadas por uma criatura grotesca e inumana, mas sim diante de um romance que quer ser lido como uma obra histórica, plena de realidade e saturada de vivências pessoais concretas (MAZZARI 1999: $50)$.

Quanto ao ponto de vista ideológico, na concepção de Boris Uspensky, semiótico russo, é importante verificar "[...] que ponto de vista assume o autor quando avalia e percebe ideologicamente o mundo que descreve" (USPENSKY 1981: 12). Grass não expõe explicitamente sua opinião. Oskar não se interessa pelo mundo externo ao seu, ou melhor, ele o observa, mas não o critica nem tenta mudá-lo. Tudo que o personagem/narrador faz tem o objetivo prático de desenvolver as habilidades que aprecia e seguir vivendo, sem ser incomodado pelos “adultos”, em sua realidade particular. Sua visão social soava mais como a de um antropólogo em observação que a de um crítico. Em praticamente nenhum momento Oskar fez algum julgamento de valor de certo ou errado em relação a alguma atitude, baseado nos critérios morais vigentes. Nós leitores sabemos de tudo, pois Oskar sabe de tudo. Avaliamos os parceiros de cena de Oskar pelas atitudes que o personagem testemunha e divide conosco. Sobre os adultos de sua convivência, constatamos em diversos trechos as avaliações do pequeno observador:

[...] a relação entre os adultos e seus relógios é sumamente singular e, mais do que isso, infantil, infantil num sentido em que, como criança, eu nunca fui (GRASS 1982: 77).

[...] Rodeadas de crianças, algumas de minha idade, lembravam-me a porca de tio Vinzent em Bissau, que às vezes, deitada de lado, tolerava o violento assalto, igualmente sedento, de seus leitões.

Os meninos debruçavam-se sobre os jorros verticais das bacias e, com o cabelo caindo para frente, deixavam que os jorros lhes entrassem pela boca. Não sei se brincavam ou bebiam. Vez por outra dois deles se levantavam quase simultaneamente com as bochechas estufadas, e com um desagradável gorgolejar cuspiam a água tépida contida na boca, misturada certamente com saliva e migalhas de pão, na cara dos outros (GRASS 1982: 90).

Tudo o que mamãe jogava na cara de Matzerath era verdade e, contudo, como sabemos, não o era (GRASS 1982: 101).

[...] e falavam de mim, Oskar, como de uma cruz que tinham de carregar, um destino cruel e sem dúvida irrevogável, uma provação que não sabiam como tinham podido merecer (GRASS 1982: 101).

Jan Bronski tinha medo (GRASS 1982: 281). 
Kunrath, M. - Uma análise de O tambor de Günter Grass

Mesmo afirmando que as observações de Oskar não possuíam qualquer traço de julgamento, a forma como as situações são descritas afeta naturalmente a nós leitores (tantos os contemporâneos que travam contato com $O$ tambor nos dias de hoje, quanto os leitores alemães do ano de estreia da obra). O narrador/personagem não compartilha do mesmo padrão de valores de seus contemporâneos: suas observações sociológicas são meras constatações do artista. O autor, pelo contrário, conhece a linha de pensamento (e talvez se importe?) de seus contemporâneos e sabe que comparar crianças a porcos ou qualificar a atitude de adultos de infantil são críticas contundentes ao modo de ser e de agir das pessoas. $\mathrm{O}$ autor, portanto, apresenta indiretamente o ponto de vista pretendido. Observamos ainda que não há opiniões diferentes expostas durante a narrativa, tampouco questionamentos ou debates acerca do modo como os demais personagens agem. Oskar é o único observador neutro. Nós, porém, leitores, não o somos.

\section{Aspectos da história do autor e da personagem}

Tal como Günter Grass, Oskar descende do povo cassúbio, ${ }^{3}$ eslavos que ocupavam a faixa ao oeste e sudoeste de Danzig (atual Gdańsk, Polônia), e ambos não escondem o seu maior apreço por essa parte da família - embora autor e personagem tenham escolhido posteriormente viver na Alemanha e falar a língua dos “conquistadores". Segundo sua autobiografia, escrita em 2006, Grass já teria confeccionado um livro (não publicado, um exercício juvenil do aluno) sobre a história dos cassúbios (GRASS, 2007: 34).

O comportamento da avó de Oskar, Anna Bronski, é um prenúncio do enredo inusual do livro. Em 1899, a mãe de Oskar é concebida no momento em que um fugitivo se esconde embaixo de suas quatro saias. Oskar detém-se longamente na explicação de como as peças de vestuário eram utilizadas, limpas e, de certa forma, como faziam parte da personalidade da avó e de um mundo que, com o advento da guerra, acabou se perdendo. As saias também remetem ao esconderijo de Oskar, a sua única possibilidade de simular um retorno à segurança do útero materno. Já a história do avô, o fugitivo,

\footnotetext{
${ }^{3}$ Segundo o autor em sua autobiografia, o grupo étnico era desprezado por poloneses e alemães, "Quando com a última guerra, os alemães mais uma vez caíram sobre eles, muitos cassúbios foram classificados por decreto 'Grupo Popular Três'. Isso aconteceu sob a pressão das repartições e na condição de experiência, a fim de que se fizessem deles alemães do reich completos; as mulheres jovens passariam a poder ser chamadas para servir como trabalhadoras, os jovens homens como o tio Jan, que de então em diante se chamou Hannes, para servir na guerra." (GRASS 2007: 35)
} 
Kunrath, M. - Uma análise de O tambor de Günter Grass

também é contada com traços extraordinários, e o próprio Oskar a encara como uma fábula, uma pressuposição: a história dos homens da família, tal como a repetida dúvida acerca da paternidade de Oskar, não parece oferecer nenhuma segurança e carece inclusive de grande relevância para a trama.

Oskar segue apresentando outros personagens importantes para a história. A avó muda-se para cidade com a mãe, Agnes, e o tio de Oskar, Jan. Quando estão com 15 anos, os adolescentes começam a se interessar um pelo outro. Oskar não se refere com grande entusiasmo ao tio, que futuramente descobriremos ser provavelmente seu pai verdadeiro. Pelo contrário, expõe a condição doentia do tio pelo fato de ele não ter sido convocado diretamente para lutar na Primeira Guerra Mundial:

Três vezes Jan tinha sido convocado para o alistamento e sempre fora declarado incapaz por causa de sua deplorável condição física; isso de fato lança muita luz sobre sua natureza enfermiça, naqueles dias em que qualquer homem que pudesse parar meio ereto era mandado a Verdun para, em solo francês, submeter-se a uma radical mudança de postura, da vertical para a perpétua horizontal (GRASS 1982: 45).

No parágrafo ainda observamos, através de Oskar, a opinião negativa de Grass em relação à Primeira Guerra Mundial: não há referência à guerra, ao patriotismo ou ao heroísmo, apenas à juventude perdida estupidamente em nome de uma causa qualquer.

A mãe de Oskar opta pelo alemão, mas não abre mão do primo polonês. Eles se casam em 1923, e a condição da família passa a ser pequeno-burguesa, com a aquisição e o sucesso de um mercadinho. Oskar nasce em 1924, e a data é extremamente significativa para o entendimento do romance no contexto alemão do pós-guerra. Günter Grass nasceu em 1927, e essa data foi citada por Helmut Kohl ${ }^{4}$ como Gnade der späten Geburt (graça do nascimento tardio), ou seja, aqueles que tiveram a benção de nascer a partir de 1927 estariam isentos da responsabilidade alemã pelo nazismo e pela guerra. ${ }^{5} \mathrm{O}$ argumento seria de que as crianças nascidas a partir daquele ano não teriam tido idade suficiente para lutar na guerra por convicção e, ao mesmo tempo, não teriam tido a possibilidade de conhecer qualquer coisa que não fosse o regime de Hitler, já que todas as instituições, desde as escolas até o sistema jurídico, estariam fundamentadas na

\footnotetext{
${ }^{4}$ Chanceler alemão entre 1982 e 1998.

${ }^{5}$ Esta é uma opinião pessoal da autora deste artigo. A frase citada por Helmut Kohl foi dita numa entrevista apenas nos anos 1980, Além disso, a validade de tal justificativa é extremamente controversa.
} 
Kunrath, M. - Uma análise de O tambor de Günter Grass

ideologia nazista. Grass pertence a essa geração. Também Oskar, apesar de ter nascido em 1924, graças à sua aparência infantil, "escapa” da culpa coletiva.

Atualmente, o argumento utilizado por Kohl é muito criticado - e talvez a questão da data apareça no livro de forma provocativa - já que aparenta uma forma de "safar-se" de algo que deveria ser assumido coletivamente. O termo, criado por um jornalista, ${ }^{6}$ foi utilizado por Kohl numa visita a Israel nos anos 1980 e causou, entre outras gafes, grandes constrangimentos diplomáticos. Segundo a revista Der Spiegel (36/1983), “A 'graça do nascimento tardio', assim acreditava o chanceler de 53 anos, lhe daria a firmeza de encarar, mesmo um homem como Begin, ${ }^{7}$ imparcialmente nos olhos. ${ }^{" 8}$ (ANÔNIMO 1983: 35, tradução nossa). Para Monika Köpcke, da emissora de rádio alemã Deutschlandradio, o uso da expressão demonstrou “[...] que ele, Helmut Kohl, não é pessoalmente culpado daquilo tudo" (KÖPCKE 2004, tradução nossa). Ela cita o chanceler na ocasião de seu discurso nos anos 1980: "Eu falo a vocês como alguém que não podia ser culpado pelo período nazista, pois eu tive a graça do nascimento tardio e a sorte de ter tido uma casa paterna especial" ${ }^{10}$ (KÖPCKE 2004, tradução nossa). Kohl explica, apenas seis anos depois da fatídica visita, a sua verdadeira intenção com o uso da expressão: “A graça do nascimento tardio não é um ganho moral da minha geração, para que pudesse ser eximida do envolvimento na culpa. Graça significa aqui não mais que o acaso da data do nascimento"11 (KÖPCKE 2004, tradução nossa).

Na ocasião de seu nascimento, o tocador de tambor, já plenamente desenvolvido espiritual e intelectualmente, descreve as cenas em seus detalhes, como a traumática

\footnotetext{
${ }^{6}$ Günter Gaus teria dito a frase para Kohl em 1982. Ele alega que foi mal interpretado pelo chanceler e que suas palavras não significariam, de modo algum, um álibi para os alemães mais novos, mas sim referia-se ao sentido da palavra "graça" como foi concebido por Martinho Lutero na teologia da justificação: uma imerecida e salvadora benção apesar do pecado original. Disponível em: <http://www.spiegel.de/spiegel/print/d-13519977.html>. Acesso em: 28 abr. 2018.

${ }^{7}$ Primeiro ministro de Israel entre 1977 e 1983, Menachem Begin nasceu em território russo em 1913. Em 1929, pelas ideias sionistas foi enviado para Sibéria e, na época do nazismo, fugiu da Polônia ocupada para lutar na resistência russa/polonesa. Teve os pais mortos em campos de extermínio. Ele havia justamente renunciado ao cargo de primeiro-ministro semanas antes da visita oficial de Helmut Kohl.

8 "Die ,Gnade der späten Geburt', so glaubte der 53jährige Kanzler, gebe ihm die Standfestigkeit, selbst einem Mann wie Begin unbefangen vor die Augen zu treten.

9 “[...] dass er, Helmut Kohl, ganz persönlich an alledem nicht schuld ist."

10 "Ich rede vor Ihnen als einer, der in der Nazizeit nicht in Schuld geraten konnte, weil er die Gnade der späten Geburt und das Glück eines besonderen Elternhauses gehabt hat."

11 "Die Gnade der späten Geburt ist nicht das moralische Verdienst meiner Generation, der Verstrickung in Schuld entgangen zu sein. Gnade meint hier nichts weiter als den Zufall des Geburtsdatums.”
} 
Kunrath, M. - Uma análise de O tambor de Günter Grass

separação da mãe e as expectativas geradas pela sua chegada. O pai logo o imagina assumindo os negócios da família: “- É macho - disse aquele Sr. Matzerath, que se presumia meu pai. - Quando crescer vai tomar conta do nosso negócio”. E a mãe anuncia: "Quando o pequeno Oskar completar três anos, vai ganhar um tambor de brinquedo" (GRASS 1982: 53). As promessas despertam uma profunda reflexão no recém-nascido, que decide dali em diante o curso de sua vida. Ele resolve, naquele momento, quando irá parar de crescer para não fazer parte daquele mundo hipócrita: "[...] a partir de meu terceiro aniversário, não cresci nem um dedo a mais" (GRASS 1982: 69).

Ao contrário do personagem Oskar, Grass não pôde nem refrear seu crescimento, nem lembrar-se com exatidão do momento de seu nascimento e dos anos que se seguiram: “[A recordação] Inclina-se a embelezar as coisas e gosta de enfeitar, muitas vezes sem motivo" (GRASS 2007: 10).

Grass ainda dota seu herói, além da reflexão e de percepção precoce de mundo e de talentos tamborísticos, de um poder "vitricida". Essa faculdade, considerada por ele um dom artístico - e Oskar insiste que sua principal motivação, no mundo do qual não queria fazer parte, é sempre artística -, possibilita à criança ter todas suas vontades atendidas e focar-se em seus objetivos:

[...] a faculdade de colocar entre mim e os adultos, por meio de meu tambor de brinquedo, a distância necessária revelou-se pouco depois da queda, quase simultaneamente ao desenvolvimento de uma voz que me permitia sustentar uma nota tão vibrante e demorada em meu canto, meu grito, meu canto gritado, que ninguém se atrevia a me retirar o tambor que lhe estropiava os ouvidos [...] Eu tinha o dom de estilhaçar vidro com meu canto (GRASS 1982: 73).

Este é Oskar, sem nenhum traço infantil no interior nos seus 94 centímetros de altura. Mas exteriormente apresentava-se como uma criança destrutiva, barulhenta (para os leigos, que não conseguiam admirar seus talentos tamborísticos) e mentalmente deficiente (já que não falava). Ele se explica: "Somente crianças que brincam são destrutivas por gosto. Eu nunca brincava, mas trabalhava com meu tambor, e, quanto à minha voz, os poderes miraculosos foram mobilizados, no começo ao menos, somente em autodefesa” (GRASS 1982: 75). Ao usar seu tambor de lata, ao contrário do que os adultos pudessem pensar, seu poder destruidor não consistia numa brincadeira ou birra infantil, mas sim em autodefesa no exercício de sua arte. O tocar do tambor não era brincadeira, e sim um trabalho. Logo o primeiro tambor de lata danificou-se pelo uso, como aconteceria com os seguintes, e era com a ameaça de quebrar outros objetos de 
Kunrath, M. - Uma análise de O tambor de Günter Grass

vidro da casa que Oskar conseguia mensalmente um novo tambor para exercitar um de seus dons. A arte vitricida também se desenvolveu conforme a necessidade de manipulação de Oskar:

Para limitar os danos, pois sempre fui um amante dos artigos de vidro, especializei-me, quando tentavam me subtrair o tambor à noite ao invés de me permitir que o levasse comigo para cama, em despedaçar uma ou mais lâmpadas do lustre do nosso quarto (GRASS 1982: 78).

Quanto aos adultos, supostamente os mais fortes e sensatos, estes eram manipulados e respondiam medrosamente a qualquer desejo do "monstro" que não podiam controlar. Afinal, ele era apenas uma criança. A forma como a "criança" nos relata suas atitudes, a reação dos adultos e a justificativa dos seus atos horrorizam qualquer mente sã. Não é à toa que a sociedade que recebeu a obra escandalizou-se com a narrativa de Oskar e seu tambor. Além da amoralidade, percebemos traços de deboche e uma arrogância indisfarçada no personagem que acredita conhecer e compreender tudo. O que mais ofende, porém, é que essa suposta sabedoria não é utilizada para corrigir o que estava errado, mas sim tirar proveito da situação em benefício próprio.

Rosenfeld comenta a respeito do herói de $O$ tambor: "Esse anão de inteligência razoável, mas cujo desenvolvimento moral parou aos três anos, tem uma semelhança grotesca com a humanidade" (ROSENFELD 1993: 238). Talvez esta seja a característica mais assustadora do romance.

Oskar, na busca por formação complementar, como aprender a ler, aceita ingressar no ensino fundamental, mas não se adapta ao sistema e qualifica a todos como gentalha incapaz de compreender seu verdadeiro talento. Após ser impedido de continuar tocando o tambor e quebrar os óculos da professora com a voz, o pequeno Oskar deixa a escola. Inicia então a busca de um substituto que pudesse ensiná-lo o ABC. O percurso, contudo, não segue a esperada evolução por etapas que os outros protagonistas vivenciam.

Já mais velho, Oskar continua observando exemplos da dissimulação dos adultos. A mãe saía semanalmente com o filho para comprar um novo tambor (eles não duravam mais que uma semana devido aos extensos treinos de Oskar). Depois da compra, encontrava-se com Jan numa pensão barata e deixava o pequeno esperando junto à proprietária por três quartos de hora. Depois de um tempo, passou a deixar o menino com o vendedor de brinquedos com uma desculpa qualquer. Em um dos passeios da mãe, Oskar foge do vendedor de brinquedos (o judeu, também apaixonado por Agnes) e acaba 
Kunrath, M. - Uma análise de O tambor de Günter Grass

na Torre da cidade, de onde grita, pela primeira vez, sem ser ameaçado ("Ninguém queria tomar o tambor de Oskar e, contudo, ele gritou." - GRASS 1982: 126), quebrando grande parte das vidraças da cidade.

Ao tocar seu tambor ou exercer o poder de sua voz, Oskar procura dar uma relevância artística a cada performance. Curiosamente, apenas ele percebe o intento da arte pela arte. $\mathrm{O}$ apreço à arte provinha de uma herança familiar: tanto a mãe de Oskar como a mãe de Grass tinham inclinações artísticas e oportunizaram o acesso das crianças ao mundo artístico. Grass relata em sua autobiografia como a mãe o incentivava a colecionar reproduções triviais de obras de arte (figuras que eram trocadas pelos vales nas carteiras de cigarro) e seguidamente tomava a lição, para ver se ele as conhecia de cor. Oskar acredita que a mãe percebeu sua aproximação artística ("Ao trucidar com meu canto as vidraças das janelas do saguão do Teatro Municipal, procurava eu, e estabeleci pela primeira vez, contato com a arte cênica" - GRASS 1982: 131) e por isso o levou posteriormente ao teatro, à ópera, ao circo e às tribunas.

Também a descrição de Matzerath, pai de Oskar, assemelha-se ao que Grass diz de seu pai: um oportunista. Apesar de ter ingressado no partido antes de sua obrigatoriedade, ou antes de que a não participação atrapalhasse os negócios, não o fez por convicção, mas como um caminho natural para os alemães que ali habitavam. Posteriormente, Oskar descreverá o pai presuntivo, quando acena para um navio, sem nem saber o porquê:

Mas esse era seu hábito: sempre fazia sinais quando os outros o faziam, e sempre gritava, ria e aplaudia quando os outros gritavam, riam ou aplaudiam. Por isso também, ingressara no partido relativamente cedo, quando ainda não era necessário, não lhe rendia nada e somente lhe ocupava as manhãs de domingo (GRASS 1982: 186).

O historiador Tony Judt questiona-se a respeito do poder de sedução nazista, sublinhando que ele foi capaz de atrair até àqueles que não eram necessariamente partidários convictos de Hitler: "Por que, afinal de contas, tantas mentes talentosas (para não falar milhões de eleitores e militantes) foram atraídos por promessas e profetas? Devido aos horrores e temores da época?" (JUDT 2008: pos. 387).

Quando em 1933, Oskar passa a atrapalhar os eventos nazistas tocando seu tambor de lata, o anão explica sua oposição ao nazismo de forma muito sincera e desconfortável:

[...] que não vejam em mim senão um indivíduo algo solitário que, por motivos pessoais e evidentemente estéticos, e tomando a peito as lições de seu mentor Bebra, rejeitava a 
Kunrath, M. - Uma análise de O tambor de Günter Grass

cor e o corte dos uniformes e o ritmo e o volume da música habitual nas tribunas, e que por isso tratava de exteriorizar seu protesto servindo-se de um simples tambor de brinquedo (GRASS 1982: 152).

Mazzari confirma a versão de Oskar, que “[...] rejeita qualquer sentido político a seus atos de sabotagem; ele dá a entender que agiu unicamente por razões estéticas" (MAZZARI 1999: 168). Toda a conduta do jovem baseava-se em suas aspirações artísticas e, embora Oskar acreditasse em sua inclinação pela harmonia, sua obra não se baseava numa beleza clássica: Ele mesmo admite: "Minha obra era, pois, de destruição. E o que não conseguia destruir com meu tambor, fazia-o com minha voz” (GRASS 1982: 152).

Grass, ao contrário de sua criatura, afirma que se questionou a vida inteira a respeito das atitudes tomadas naquele período. Em sua autobiografia, exercita a memória em busca de respostas: por que, afinal, apesar de já não ser mais criança, ele não questionou os acontecimentos?

E também eu, ainda que com o princípio da guerra minha infância tenha acabado, não fiz perguntas repetitivas.

Ou será que não ousava perguntar porque não era mais criança?

Será que, assim como nos contos de fadas, só as crianças fazem as perguntas certas?

Ou será que o medo de uma resposta que pusesse tudo de ponta-cabeça me tornou mudo? (GRASS 2007: 16)

Posteriormente, confessa que sua moral e exigência por justiça estava presente, mas de forma completamente seletiva: "Cego para as injustiças que se tornavam cotidianas nas cercanias mais próximas da cidade [...] perturbavam-me apenas os crimes do poder clerical e as práticas de tortura da Inquisição" (GRASS 2007: 33).

Para mostrar repúdio às práticas do passado, que o revoltavam, Grass, inclusive, começou a escrever, embora não fosse capaz de enxergar o que estava diante de seus olhos: “[...] minha primeira tentativa de escrever, bem volumosa segundo os planos, conseguiu se manter distante da deportação dos judeus restantes de Danzig para fora do gueto da Mausegasse ao campo de concentração de Theresienstadt [...]" (GRASS 2007: 33).

Oskar, como personagem amoral, não possuía necessariamente nenhuma restrição ao nazismo, pelo menos não maior do que ao mundo adulto em si. Porém, por trás da posição acrítica do anão, percebemos para onde exatamente Grass pretende nos orientar: inspirando o desprezo pelo personagem que é incapaz de julgar os malfeitos da sociedade 
Kunrath, M. - Uma análise de O tambor de Günter Grass

que o cerca, o autor nos provoca a uma reação indignada que suscitará reflexão. Neuhaus (1997) nota a insistência (e inovação) do autor em expor os participantes do regime como pessoas que poderiam estar muito próximas de nós, ou então ser, até mesmo, nós próprios:

Grass mostra com isso que os nazistas, que até agora não haviam aparecido na Literatura Alemã ou apareceram como sem nome, ou como "os outros", se chamavam Matzerath, Greff, Scheffler e Meyn e eram sangue do nosso sangue e carne da nossa carne. ${ }^{12}$ (NEUHAUS 1997: 13, tradução nossa).

Em sua análise, Mazzari comenta sobre como Matzerath fechou a mercearia e trancou-se em casa durante a noite dos cristais:

O honrado comerciante Alfred Matzerath, sujeito de bom coração, e exemplar pai de família, aquecendo as mãos e sentimentos na fogueira, mostra-se conivente com o crime coletivo, dá o seu aval ao genocídio que então se desencadeia (MAZZARI 1999: 175).

A influência de uma demanda moral está então presente em todo $O$ tambor. Não da parte de seu personagem principal, o anti-herói Oskar Matzerath, mas na atitude julgadora e voyeurista de seus leitores, nós, que a todo momento avaliamos e sentenciamos os relatos isentos (pelo menos do que reconhecemos por moral) de Oskar. Grass também se lembra da noite citada, mas a avalia de forma diferente da de seu protagonista: "Quando pouco depois do meu décimo primeiro aniversário as sinagogas queimaram em Danzig, e também outros lugares e vitrines se quebraram em cacos, eu permaneci inativo, mas junto aos fatos na condição de espectador curioso [...]" (GRASS 2007: 23).

As experiências artísticas de Oskar possuíam grande afinidade com questões morais. Numa de suas performances, agora às escondidas, praticava a "arte da sedução". Tal jogo consistia em induzir as pessoas ao roubo. Primeiramente procurava um "cliente":

O tipo de cliente que eu esperava, em meio ao frio seco e sem vento, [...] era daqueles que paravam diante das vitrines como que obedecendo a um apelo e não procuravam muito nas prateleiras, mas rapidamente pousavam o olhar em apenas um dos objetos expostos (GRASS 1982: 155).

Depois do alvo escolhido, “[...] cabia-me induzir” (GRASS 1982: 156); Oskar deixava então o objeto desejado ao alcance de seu cobiçoso:

[...] com um grito absolutamente inaudível, eu cortava o cristal da vitrine, exatamente na altura do plano inferior e, se possível, diante do objeto desejado, com incisões circulares,

12 “[...] Grass zeigt dabei, da $\beta$ die Nazis, die bislang in der deutschen Literatur gar nicht oder namenlos oder als "die Anderen" vorkamen, Matzerath, Greff, Scheffler und Meyn hießen und Fleisch von unserem Fleisch, Bein von unserem Bein waren." 
Kunrath, M. - Uma análise de O tambor de Günter Grass

e com uma última elevação da voz empurrava o vidro recortado até as prateleiras [...] (GRASS 1982: 152).

Nem sempre a cuidadosa observação do comportamento humano alcançava as expectativas do indutor. Ao expor casais de namorados aos "produtos": "Acontecia sempre que ou os dois não queriam ou, quando ele estendia a mão, ela o impedia; ou então era ela quem tinha a coragem enquanto ele se ajoelhava e implorava, até que ela obedecesse - e a partir daí o desprezava para sempre” (GRASS 1982: 157).

A dinâmica, desde sua motivação até a conclusão do ato, apresenta um estudo sobre o comportamento humano principalmente em sociedade. As pessoas mais respeitáveis só procediam ao furto sob os segredos das sombras e sob a proteção do anonimato. Agiam como se uma espécie de destino as tivesse colocado ali. Por outro lado, se estivessem acompanhadas, modificavam seu comportamento moral frente ao julgamento do outro. Grass nos propõe a observação da conduta do indivíduo em sociedade, a partir da provocação de Oskar, como uma prática em outras esferas públicas. No momento em que todos são cúmplices em vandalizar sinagogas, amparados inclusive pelo âmbito legal, não há uma moralidade superior para questionar tais atitudes. Aparentemente as leis sociais não são imanentes ao ser humano, e, quando a premissa muda, o sujeito adapta-se para ser aceito e gozar dos mesmos privilégios que obtinha com outros princípios. E Oskar? Oskar é apenas o mensageiro que nos conduz a esta conclusão. E quanto aos pobres tentados, tiveram azar pois “[ [...] jamais teriam suspeitado que sua natureza fosse propensa ao roubo, se a voz de Oskar não os houvesse induzido a isso [...]" (GRASS 1982: 160).

Com a morte da mãe, Oskar, já com 14 anos, encontra-se em situação precária e a culpa por isso: “... com a partida de mamãe meu abastecimento regular de tambores se tornara problemático" (GRASS 1982: 208); "Minha mãe morreu - procurei explicar. - Ela não devia ter feito isso" (GRASS 1982: 209). O pai presuntivo, os vizinhos e mesmo clientes da mercearia deixam claro a Oskar, não tão veladamente (já que ele "não entende nada"), que a mãe optara por morrer de desgosto. Reencontra ainda seu mestre Bebra, um palhaço anão que o orienta na arte e na vida, que o consola, chegando à conclusão diretamente oposta às dos vizinhos e amigos do pai: "Sente-se humilhado porque não foi você e sim esses cansativos amantes que a mandaram para o túmulo. Você é mau e vaidoso, o que é próprio dos gênios" (GRASS 1982: 209). 
Desnorteado, sem o cuidado da mãe, Oskar circula mais livremente e, de certa forma, sem objetivo. O pequeno presencia mudanças nítidas em seu meio: o ano é 1938 , e a evolução do regime nazista fica cada vez mais visível. Ainda no enterro da mãe, o judeu Marcus, dono da loja de brinquedos e apaixonado por ela, foi impedido de assistir ao funeral. $\mathrm{O}$ jovem anão segue percebendo uma significativa melhora na qualidade de vida dos cidadãos: "Desde a tomada do poder por Hitler cada vez crescia mais o número de aspiradores no edifício [...]" (GRASS 1982: 214). Por fim, relata, com pinceladas de fábula, a completa inversão de valores e a iminência de grandes mudanças. O músico Meyn, vizinho e membro da SA, foi acusado de ter matado seus quatro gatos:

E ainda que na noite de oito para nove de novembro de trinta e oito, que mais tarde haviam de chamar Noite de Cristal, o SA se distinguisse por seu valor, incendiando junto com os outros a sinagoga de Langfuhr da Rua de São Miguel e colaborando também ativamente, na manhã seguinte, na invasão de algumas lojas previamente assinaladas, todo esse fervor não impediu que o SA fosse expulso da SA montada. Foi degradado por crueldade inumana com os animais e riscado da lista de membros (GRASS 1982: 246).

A passagem irônica, relatando os grandes "feitos" do $S A^{13}$ contra seres humanos, demonstra que a violência inumana contra os animais não seria tolerada. Oskar continua com seu presságio:

Era uma vez um tambor chamado Oskar. Quando lhe tiraram o vendedor de brinquedos e saquearam a loja do vendedor de brinquedos, teve o pressentimento de que para os tambores anões de sua espécie se anunciavam tempos calamitosos (GRASS 1982: 248).

A existência de Oskar, apenas suportável pela posse de seu instrumento, foi posta em xeque pelo próprio. Como continuar vivendo em um mundo cada vez mais alterado, sem um mínimo de segurança, ou seja, sem um fornecimento regular de tambores? Novamente uma alegoria da situação de instabilidade cada vez mais presente na vida dos perseguidos (comunistas, ciganos, judeus, homossexuais, entre outros) e mesmo dos cidadãos que ainda acreditavam em algumas leis básicas que regiam a humanidade. Oskar logo tomou providências para que pudesse continuar existindo.

Sem imaginar como poderia continuar vivendo sem seu tambor, Oskar procura ajuda de seu suposto pai verdadeiro, funcionário do correio polonês, e o obriga, no

\footnotetext{
${ }^{13}$ Abreviatura de Sturmabteilung (traduzido usualmente por "tropas de assalto" ou "departamento de assalto"), milícia paramilitar, liderada por Röhm, era composta pelos "camisas pardas" (também chamados de SA). Mais do que um exército particular de Hitler, era constituída por baderneiros encarregados de desestabilizar o regime. Depois de conquistar determinadas esferas do poder, Hitler tratou de descartar o grupo, perigoso e difícil de controlar. Os remanescentes mais fiéis acabaram ingressando na SS.
} 
Kunrath, M. - Uma análise de O tambor de Günter Grass

momento em que o correio será tomado pelas forças nazistas alemãs, ${ }^{14}$ a retornar ao perigoso local para que o zelador, que trabalhava no correio, pudesse consertar seu tambor de lata. A ideia fixa de Oskar é conseguir o conserto de seu tambor, não importando exatamente as consequências de seus atos ("“...] caso não conseguisse encontrar o zelador a tempo, ou seja, antes do assalto final, que era de se esperar com segurança, mal poderia pensar na restauração de minha lata.” - GRASS 1982: 273). Em meio ao caos, metidos sem querer na defesa do correio, Jan, Oskar e o zelador Kobyella, já fatalmente ferido, escondem-se em uma sala, onde estão outros combatentes mortos. Em uma cena bizarra, o anão propõe uma partida de skat (jogo de cartas com o número indispensável de três pessoas) para acalmar os ânimos. "Que podíamos fazer sem o terceiro homem indispensável para o skat?" (GRASS 1982: 293). Aparece então a capacidade do pequeno de distanciar-se da realidade (apesar de percebê-la) e focar-se em qualquer outra coisa "irrelevante" - tal como fizeram milhares de civis alemães, não percebendo a urgência de combater um regime, não apenas desumano, mas que os levaria à ruína. Oskar observa: "Na realidade, tampouco Kobyella tinha disposição para jogar skat. O que queria era se deitar... Como não podíamos permitir semelhante fatalismo, atamo-lo e o forçamos a entrar de terceiro parceiro..." (GRASS 1982: 293). Jan, também fora da realidade, mas de uma forma diferente de Oskar, participa da farsa sob as ordens do anão, que parece estar seguro da situação, e procura ajudar o colega de trabalho:

Apesar dos suspensórios, de novo estava caindo. Voltamos a endireitá-lo e esperamos que se apagasse o ruído de um impacto de granada em algum lugar afastado do nosso quarto, para que Jan cochichasse, ao restabelecer-se o silêncio: "Vinte e quatro, Kobyella. Não ouviu o menino cantando?" (GRASS 1982: 293).

Assim, os dois jogadores vivos esperavam poder continuar o jogo - e, por que não, a vida - com um verniz autêntico de normalidade. Oskar, ciente da situação, mas assumindo, por hora, sua responsabilidade, se mostra pela primeira vez, não como criança, mas como rapaz de 15 anos e credita a sua atitude ao desejo de combater o medo

\footnotetext{
${ }^{14}$ A Polônia foi invadida em $1^{\circ}$ de setembro de 1939 . O ato inicial da guerra consistiu num assalto das forças militares alemãs à fortificação polonesa na península de Westerplatte, dentro do território da Cidade Livre de Danzig (que desde 1933 jazia sob controle político do Partido Nacional-Socialista). Simultaneamente, forças nazistas locais atacaram o prédio do correio de Danzig. Exigiu-se a sua entrega pelas forças polonesas de defesa no prazo de duas horas. Na ocasião, funcionários civis do correio polonês, que possuíam treinamento militar e armas escondidas no local, ofereceram 15 horas de resistência contra a invasão. Após a tomada do correio, os rebeldes foram executados.
} 
Kunrath, M. - Uma análise de O tambor de Günter Grass

de seu pai presuntivo. Ele conclui: “... e proibimos Kobyella de morrer.” (GRASS 1982: 296).

Quando são capturados pelos alemães, a criança de três anos volta a aparecer, novamente para atender os próprios interesses:

Oskar como que buscando proteção se colocou entre dois milicianos de aspecto particularmente benévolo e paternal, derramou umas lágrimas de crocodilo e apontou com gestos acusadores Jan, seu pai, fazendo do infeliz um malvado que arrastara ao edifício do correio polonês uma criança inocente, para servir-se dela, de forma inumanamente polonesa, como escudo contra as balas (GRASS 1982: 304).

Ao mesmo tempo que confessa sua culpa - "Hoje, quando temporariamente me envergonho daquela atitude indigna, repito sempre: Jan nada notou" (GRASS 1982: 304) -, o protagonista culpa a influência do tambor: "[...] foi meu tambor, não, fui eu mesmo, Oskar, o tambor, quem despachou para a tumba primeiro minha pobre mãe, depois Jan Bronski, meu tio e pai” (GRASS 1982: 305).

Günter Grass teve de fato um parente que morreu na defesa do correio polonês. $\mathrm{O}$ autor escreve sobre o assunto em sua autobiografia e, juntamente com a revelação, tece uma crítica aberta, não exatamente às atitudes tomadas no período negro do nazismo, em que o tio fora condenado à morte por um juiz, mas ao fato de a sociedade alemã ter permitido que esse mesmo juiz continuasse ativo e respeitado depois da guerra, ou seja, que não tivesse de responder pelas suas ações durante a guerra:

A guerra contava poucos dias quando um primo da minha mãe, tio Franz, que na condição de carteiro pertencia aos defensores do correio polonês na praça Hevelius, foi fuzilado pouco depois da curta batalha como quase todos os outros sobreviventes. O juiz militar, que fundamentou, pronunciou e assinou as sentenças de morte, ainda pôde sentenciar e assinar sentenças sem nenhum problema bem depois do fim da guerra, como juiz em Schleswig-Holstein. Isso era coisa comum nos tempos que pareciam não querer acabar mais do chanceler Adenauer (GRASS 2007: 15).

Oskar percebe que até um de seus mentores intelectuais pôde ser cooptado e que o mundo dos anões não o protegeria, necessariamente, de fazer parte daquele momento histórico, agora como participante e não mais apenas como observador. Bebra, frente à reação de Oskar - “[...] não quis tornar as coisas fáceis para Bebra [...]” (GRASS 1982: 381) - continua com débeis justificativas:

[...] e começou a falar dos tempos difíceis, dos fracos que temporariamente são obrigados a ceder o passo, da resistência que floresce na clandestinidade; em suma enunciou o slogan "emigração interior". Eis por que os caminhos de Oskar e de Bebra se separam (GRASS 1982: 381). 
Kunrath, M. - Uma análise de O tambor de Günter Grass

Aqui a crítica de Grass mostra-se contundente ao falar da "emigração interior". O movimento de autodefesa de muitos intelectuais alemães pela não reação diante do regime. Em alguns casos coerente, mas, em muitos, uma desculpa pela cômoda inação perante os crimes presenciados. O escritor, ao repensar o seu papel durante a guerra, procura alternativas do que poderia ter acontecido, se ele tivesse agido de modo diferente. Porém, ele mesmo observa a inutilidade do raciocínio, já que o passado não pode ser alterado:

[...] assim evitei mais uma vez as palavras "por quê", de modo que meu silêncio agora, enquanto despelo a cebola, reboa em meus ouvidos.

Admito: uma dor que me torturava bem pouco. Mas queixas [...] são surradas, e na condição de eco têm como conseqüência no máximo aquela gargalhada que o trocista que há em mim larga assim que desculpas do tipo começam a se manifestar: se nós na época tivéssemos feito... Se nós na época fôssemos...

Mas eu não fiz, eu não fui (GRASS 2007: 23).

A decepção de Oskar não o impediu de seguir com a trupe ao reencontrarem-se em 1942. Avaliando que ainda teria dois anos para cumprir sua promessa para com o filho (“Quando fizer três anos terá um tambor de lata." - GRASS 1982: 372), Oskar aceita trabalhar para o exército alemão. Durante os dois anos, os lilliputianos frequentam o teatro de guerra: vão a Paris, apresentam-se para as tropas, visitam casamatas, como se fossem soldados que não lutam. Para Oskar e seus companheiros do teatro de campanha a guerra não era senão um espetáculo, no qual todos interpretavam papéis segundo as vantagens e oportunidades que apareciam.

$\mathrm{Na}$ verdade, a guerra era, no livro de Grass, um jogo de interesses para todos os participantes, voluntários ou involuntários. As pessoas se adequavam e sobreviviam de uma forma ou de outra nesta nova organização. Os escrúpulos e valores morais mudavam conforme as necessidades sociais. Em diversas cenas, segundo os relatos, as apresentações mostram-se como uma forma de alienar os soldados da triste realidade em que viviam. Mazzari comenta, quando uma exibição é feita dentro de um abrigo antiaéreo: “[...] podemos reconhecer a função desumana e alienante da Companhia teatral de Bebra - seu público aparece como uma massa sepultada, que precisa ser distraída a todo custo das condições reais de sua existência" (MAZZARI 1999: 104).

Em 1945 a família Matzerath morava no porão da mercearia por causa da ameaça das bombas, e a chegada dos russos era iminente. O chefe da família, que durante a guerra 
Kunrath, M. - Uma análise de O tambor de Günter Grass

pertencera ao partido nazista, ainda guardava a insígnia com a suástica. Ele teria de livrarse dela antes de ser preso pelos russos, mas Oskar acaba tomando-a. No momento oportuno, na presença dos soldados russos, devolve-a a Matzerath, que, em pânico, a coloca na boca, com o alfinete aberto, e engasga, assustando assim seus algozes que o alvejam com suas metralhadoras:

Oskar confessava a si mesmo que o tinha matado deliberadamente porque, segundo todas as probabilidades, Matzerath não era somente seu pai presuntivo, mas também seu pai verdadeiro, e Oskar já estava farto de ter de carregar pela vida afora um pai (GRASS, 1982: 502).

Com a morte dos "responsáveis" por ele (a mãe, o pai/tio, e o pai presuntivo), Oskar sente que é o momento de assumir responsabilidades - afinal, alguém precisa tomar conta de sua eterna amante e de seu filho. Enterra seu tambor e decide recomeçar a crescer (do que se arrepende posteriormente): “... e também eu comecei a crescer; uma forte hemorragia nasal foi o sintoma" (GRASS 1982: 504). O herói, ou anti-herói, passa de uma figura infantil, que provoca os mais variados instintos maternais, para uma figura grotesca, corcunda e deformada. A retomada do crescimento não foi física nem psicologicamente fácil para o jovem: o corpo mal conseguia suportar o doloroso processo do súbito desenvolvimento dos membros, o que provocou forte padecimento, febre alta e o conselho de procurar um hospital no oeste.

Esse é também o momento histórico da expulsão e fuga em massa ${ }^{15}$ do leste para o oeste, quando os alemães lotados nos países eslavos, ou mesmo aqueles residentes na Alemanha, mas próximos à fronteira oriental, fogem da revanche russa. A madrasta decide sair de Danzig e ir para Alemanha com o filho Kurt e Oskar.

Hoje sabemos que durante esse período histórico o escritor Grass fazia parte da SS. Ele tenta se justificar em sua autobiografia ("[...] no final da guerra, qualquer um era considerado apto a empunhar armas." - GRASS 2007: 110), mas, ao mesmo tempo se lamenta por não ter percebido antes (“[...] algo como compreensão chegou a me tocar?” - GRASS 2007: p. 107) com o que exatamente tinha se envolvido (“[...] a canção do juramento da Waffen-SS: 'Se todos se tornarem desleais, nós continuaremos leais ainda assim..."”- GRASS 2007: 107). As lembranças são obscuras, e mesmo sua testemunha mais próxima, ele mesmo, não pode confiar na memória (“A partir de então o filme rasga

${ }^{15}$ Calcula-se que entre 12 e 14 milhões de alemães tenham se deslocado para o oeste entre 1944 e 1948.

Pandaemonium, São Paulo, v. 21, n. 35, set.-dez. 2018, p. 1-23 
Kunrath, M. - Uma análise de O tambor de Günter Grass

sempre de novo. Por mais que eu o emende e volte a fazê-lo passar, ele oferece uma salada de imagens" - GRASS 2007: 110). Finalmente, o jovem Grass é salvo por um soldado mais experiente, que troca a roupa dele, com as insígnias da $S S$, por um uniforme de soldado raso, explicado a importância de estar vestido de outra forma:

[...] Nos do teu tipo eles simplesmente metem uma bala. Tiro na nuca e pronto [...] Provavelmente ele "arranjou", conforme se dizia no alemão dos soldados rasos, não sei mais onde um casaco normal da Wehrmacht (GRASS 2007: 131).

Já o narrador do romance, Oskar, não teve de presenciar a guerra como soldado. Ele ruma, junto a outros refugiados, para o oeste. Durante a penosa viagem de trem, Oskar continua enfermo por causa da retomada do crescimento e, já em Düsseldorf, permanece meses no hospital. Bruno, que escreve parte das confissões de Oskar, conclui sobre como o paciente era, na época que este deixa o hospital: "Era então um jovem que sabia falar, escrevia lentamente, lia com fluidez e, ainda que disforme, era em conjunto um homem são; podia pois - como se supõe sempre ao ter alta dos hospitais - começar uma vida nova, uma vida de adulto" (GRASS 1982: 532).

Oskar continua vivendo bem-sucedidas aventuras até o momento em que decide internar-se propositalmente num hospício e contar suas memórias (mais ou menos na mesma época em que Grass decide escrever seu romance).

\section{Conclusão}

Grass cria um protagonista que, coincidentemente, vivenciou de forma semelhante a parte das suas experiências de vida (época e local de nascimento, origem e características familiares, interesses artísticos), mas, ao contrário do autor, soube enxergar o modo como o mundo funcionava. Através do testemunho amoral de Oskar, um memorial de acusação indireta, Grass soube expor aquilo que condenava na guerra e na condução da Alemanha depois da catástrofe, e que só percebeu posteriormente:

A maneira impiedosa com que o narrador registra o comportamento das pessoas comuns (como o merceeiro Matzerath) durante o Terceiro Reich, portanto o comprometimento da maioria com os crimes então praticados, foi tachada de calúnia, falta de patriotismo, etc. Mas o que talvez mais tenha ferido a sensibilidade alemã do final dos anos 50 - início dos 60 foi a postura crítica assumida pelo narrador em face da tendência conservadora, ou mesmo restaurativa da era Adenauer, ter acusado a inexistência de uma ruptura efetiva com a mentalidade anterior (MAZZARI 1999: 188). 
Kunrath, M. - Uma análise de O tambor de Günter Grass

Da mesma maneira que estreou na literatura, de forma estridente, Grass caracterizou toda sua performance/vida pública: politicamente atuante, com opiniões fortes e provocativas, assumindo-se culpado, mas redimindo-se pela sua confissão; e coroou a polêmica carreira em grande estilo, com suas memórias, adicionando um dado chocante e ainda desconhecido à sua biografia: a participação na $S S$.

Dito isso, é ainda evidente que, independentemente das intenções do autor, ou de sua qualidade moral, a publicação de $O$ tambor gerou um saudável desconforto na sociedade alemã, a quem Grass acusava, através da sua obra de ficção, de hipocrisia por não ter combatido o nazismo e de ser conivente, enquanto lhe interessava, com o regime. $O$ tambor é parte da ruptura que permitiu aos alemães revisar suas memórias, sua culpa e sua responsabilidade durante a ditadura nazista. Para a literatura, a criação do anti-herói Oskar Matzerath também foi um marco: a agonizante literatura alemã recebeu um novo fôlego no pós-guerra e pôde, aos poucos, recompor-se e recuperar a relevância que possuía antes de 1933. O anão deformado conquistou, se não a simpatia geral, um lugar permanente no rol dos personagens literários que dispensam apresentações. A escritura de $O$ tambor também possibilitou uma renovação na discussão das formas de criação literária e sobre como os antigos modelos - como o tradicional romance de formação alemão e o romance picaresco - podem produzir novas formas de expressão.

Oskar, o personagem principal de $O$ tambor, encerra sua odisseia (e a narração de sua história) dessa forma:

Que mais tenho a dizer: nasci sob lâmpadas elétricas, interrompi deliberadamente o crescimento aos três anos, ganhei um tambor, estilhacei vidro com a voz, cheirei baunilha, tossi em igrejas, alimentei Luize com sanduíches, observei formigas, decidi crescer, enterrei o tambor, fugi para o Ocidente, perdi o Oriente, aprendi o ofício de marmorista, posei como modelo, voltei ao tambor e inspecionei cimento, ganhei dinheiro e guardei um dedo, dei o dedo de presente e fugi rindo; ascendi, fui preso, condenado, internado, sairei absolvido; e hoje comemoro meu trigésimo aniversário e a Bruxa Negra continua me assustando - amém (GRASS 1982: 735).

Também Grass, ao finalizar o romance, inicia uma nova etapa de sua vida. As suas memórias abrangem o mesmo tempo que a vida de Oskar Matzerath. O sucesso da narrativa e o engajamento político e social darão um novo sentido à vida de Grass. Quanto a Oskar, isso é uma outra história. 


\section{Referências bibliográficas}

ANONIMO. Späte Geburt. Der Spiegel, Hamburg, n. 36, 05 nov. 1983. Disponível em: <http://www.spiegel.de/spiegel/print/d-14018745.html>. Acesso em: 30 nov. 2015.

Bоотн, W. A retórica da ficção. Lisboa: Editora Arcadia,1980.

ENZENSBERGER, Hans Magnus. Wilhelm Meister, auf Blech getrommelt. In: LOSCHÜTZ, Gerd (Org.). Von Buch zu Buch: Günter Grass in der Kritik. Berlin: Luchterhand, 1968. p. 914.

FRIEDMAN, Norman. El punto de vista. In: Sullà, Enric (Org.). Teoría de la novela: antologia de textos del siglo XX. Barcelona: Crítica, 1996. p. 78-87.

GRASS, Günter. O tambor. Tradução de Lúcio Alves. Rio de Janeiro: Nova Fronteira, 1982.

GRASS, Günter. Nas peles da cebola. Tradução de Marcelo Backes. São Paulo: Record, 2007.

JUDT, Tony. Reflexões sobre um século esquecido: 1901-2000. Tradução de Celso Nogueira. Rio de Janeiro: Objetiva, 2008. E-book Kindle.

KÖPCKE, Monika. Vor 20 Jahren: Helmut Kohl trifft in Israel ein und spricht von der "Gnade der späten Geburt". KalenderBlatt, Berlin, 24 jan. 2004. Disponível em: <https://web.archive.org/web/20090819082755/http://www.dradio.de/dlr/sendungen/kal ender/227514/>. Acesso em: 30 abr. 2018.

KUNRATH, Milena. Günter Grass, Oskar e seus tambores: a tradução de uma prática interdisciplinar. 2009. Dissertação (Mestrado em Letras). Instituto de Letras, UFRGS, Porto Alegre, 2009.

MAZZARI, Marcus Vinicius. Romance de formação em perspectiva histórica: O Tambor de Lata de G. Grass. Cotia: Ateliê Editorial, 1999.

NeuHaus, Volker. Schreiben gegen die verstreichende Zeit: zu Leben und Werk von Günter Grass. München: dtv, 1997.

PouILlon, Jean. O tempo no romance. Tradução de Heloysa de Lima Dantas. São Paulo: Cultrix, Ed. da Universidade de São Paulo, 1974.

ROSENFELD, Anatol. Günter Grass. In: Letras germânicas. São Paulo: Edusp, 1993.

USPENSKY, Boris. A poética da composição: estrutura do texto artístico e tipologia das formas compositivas. Tradução de Maria Helena Kirst e Maria da Glória Bordini. Porto Alegre: 1981, [s.n.]. 